\title{
Keadilan Restorative Justice Melalui Kebijakan Diversi Dalam Sistem Peradilan Anak
}

\author{
Edi Saputra Hasibuan \\ Fakultas Hukum, Universitas Bhayangkara Jakarta Raya, Direktur Eksekutif Lemkapi \\ Email: dwi.seno@dsn.ubharajaya.ac.id, irmanjtaher70@gmail.com
}

Received : 12 Ags 2021 | Revised : 22 Sep 2021 | Accepted : 30 Sep 2021 | Published : 9 Dec 2021

\begin{abstract}
The position of the rights and obligations of everyone in court is the same, but as a special relationship in the criminal justice system, children must receive different treatment, considering that children are an inseparable part of human survival and the sustainability of the nation and state. Law no. 11 of 2012 concerning the juvenile justice system emerged as a form of intention to create child-friendly courts, even looking further at the most basic substance of this rule, namely promoting the principles of restorative justice with a view to finding a settlement of cases without having to go through a trial. However, in practice there are still child cases that continue to take legal action through the courts. These problems will then be discussed, looking at the policies and realities as well as benchmarks about what kind of cases can be resolved in every process of resolving child cases in court.
\end{abstract}

Keywords: Restorative justice, Diversion, policy

\begin{abstract}
ABSTRAK
Kedudukan hak dan kewajiban setiap orang di dalam pengadilan adalah sama, namun sebagai suatu relasi yang khusus dalam sistem peradilan pidana, anak harus mendapatkan penanganan berbeda, mengingat anak adalah bagian yang tidak terpisahkan dari keberlangsungan hidup manusia dan keberlangsungan bangsa dan negara. Undang-undang no. 11 tahun 2012 tentang sistem peradilan anak muncul sebagai bentuk niatan untuk membuat pengadilan ramah anak, bahkan melihat lebih jauh tentang substantsi yang paling mendasar tentang aturan ini, yaitu mengedepankan prinsip keadilan restorative justice dengan maksud untuk mencari penyelesaian perkara tanpa harus melalui persidangan. Namun dalam prakteknya masih ada perkara-perkara anak yang terus menempuh jalur hukum melalui pengadilan. Permasalahan itulah yang kemudian akan dibahas, melihat kebijakan dan realitas, serta tolak ukur tentang kasus seperti apa yang dapat diselesaikan dalam setiap proses penyelesaian perkara anak di pengadilan.
\end{abstract}

Kata Kunci: Keadilan Restoratif, Diversi, Kebijakan 


\section{PENDAHULUAN}

Dalam konstitusi Indonesia, anak memiliki peran strategis yang dinyatakan secara tegas bahwa negara menjamin hak setiap anak atas kelangsungan hidup, tumbuh, dan berkembang serta atas perlindungan dari kekerasan dan diskriminasi. ${ }^{1}$ Perintah yang tegas melalui undang-undang dasar ini kemudian harus ditindaklanjuti dengan membuat kebijakan pemerintah yang bertujuan melindungi dan memberikan keadilan pada anak.

Keadilan terhadap anak yang berhadapan dengan hukum yaitu dengan dipastikannya semua anak memperoleh layanan dan perlindungan yang optimal melalui sistem peradilan. Targetnya adalah norma-norma, prinsip, dan standar hak anak yang secara penuh diberikan kepada setiap anak tanpa terkecuali, baik anak yang berhadapan dengan hukum atau anak yang berkonflik dengan hukum. Berhadapan dengan hukum berarti anak tersebut dapat menjadi korban atau saksi, sedangkan berkonflik dengan hukum berarti anak tersebut berada di posisi sebagai tersangka atau terdakwa tindak pidana. ${ }^{2}$

Anak perlu mendapat perlindungan dari dampak negatif perkembangan pembangunan cepat, arus globalisasi di bidang komunikasi dan informasi, dan tentunya perlindungan hukum. ${ }^{3}$ Prinsip perlindungan hukum dalam melindungi anak harus sesuai dengan Konvensi Hak-hak Anak (Convention on the Rights of the Child) sebagaimana telah diratifikasi oleh pemerintah Republik Indonesia dengan Keputusan Presiden Nomor 32 tahun 1990..$^{4}$ Dengan adanya langkah pemerintah dengan meratifikasi konvensi tersebut maka semestinya perlindungan hukum terhadap anak dapat tercapai. ${ }^{5}$

Namun sepertinya bila melihat praktek di lapangan masih banyak anak-anak yang terlibat dalam konflik hukum diposisikan sebagai objek sistem peradilan pidana (SPP) dan hal ini tentunya dapat memberi dampak buruk terhadap perkembangan anak. Kenyataan ini melahirkan suatu niatan untuk memberikan perlindungan terhadap anak melalui sistem peradilan yang "ramah" anak yang secara substansial diatur melalui Undang-undang Nomor 11 tahun 2012.

Dalam aturan tersebut banyak hal yang disoroti salah satunya mengenai penempatan anak yang menjalani proses peradilan dapat ditempatkan di Lembaga Pembinaan Khusus Anak (LPKA), serta yang paling penting dan mendasar yaitu pengaturan secara tegas mengenai Keadilan Restoratif dan Diversi.

Berbagai kendala yang mungkin dihadapi baik dari proses penyidikan, penuntutan, maupun peradilan memang acapkali ditemui sehingga dalam menjalani

\footnotetext{
${ }^{1}$ Republik Indonesia, Undang-undang Dasar 1945 pasal 28 Huruf B

2 Hadi Supeno, "Kriminalisasi anak, Tawaran Gagasan Radikal Peradilan Anak Tanpa Pemidanaan”, Jakarta:PT. Gramedia, 2010, Hal 89

${ }^{3}$ Al Adawiah, R. (2019). Child Abuse Dan Keamanan Lingkungan Anak Dalam Menyongsong Bonus Demografi 2025-2030. Krtha Bhayangkara, 13(1). https://doi.org/10.31599/krtha.v13i1.13

${ }^{4}$ Convention on the Rights of the Child atau Konvensi hak anak adalah suatu instrumen yang merumuskan prinsip-prinsip secara universal dan norma hukum mengenai kedudukan anak. Konvensi ini merupakan perjanjian internasional yang memasukan hak dasar manusia juga hak sipil, politik, ekonomi dan budaya. Sebelum disahkan sejarah mencatat bahwa hak-hak anak melewati perjalanan yang cukup panjang dimulai dari usaha perumusan draft hak-hak anak yang dilakukan Mrs. Eglantynee Jebb, pendiri Save the Children Fund. 2 Setelah melaksanakan programnya merawat para pengungsi anak-anak,pada Perang Dunia Pertama, Jebb membuat draft "Piagam Anak" pada tahun 1923. Beliau menulis: "Saya percaya bahwa kita harus menuntut hak-hak bagi anak-anak dan memperjuangkannya untuk mendapat hak universal".

${ }^{5}$ Laksana, P. B. ., \& Sugeng. (2020). Pendekatan Keadilan Restoratif Terhadap Anak Sebagai Pelaku Pelanggaran Lalu Lintas. Jurnal Hukum Sasana, 5(1). https://doi.org/10.31599/sasana.v5i1.91
} 
perintah undang-undang ada implementasi yang berbeda. Oleh karena itu kebijakan yang ada tidak cukup sekedar mengatur namun juga terperinci serta bagi para penegak hukum harus menjiwai aturan itu sendiri.

Dari apa yang sudah dipaparkan melalui latar belakang di atas maka terdapat rumusan masalah yaitu sebagai berikut: (1) Bagaimana kebijakan diversi dalam penerapannya pada proses peradilan pidana anak serta hambatan yang membuat tidak tercapainya diversi? (2) Apa yang menjadi tolak ukur agar tercapainya restorative justice melalui diversi dalam kaitannya dengan hak berpartisipasi pada anak?

\section{PEMBAHASAN}

\section{A. Kebijakan Diversi Serta Aturan-aturan Pendukung UU SPPA (Sistem Peradilan Pidana Anak)}

Upaya untuk menghindari dan menjauhkan anak dari proses pengadilan sehingga dapat menghindari stigmatisasi terhadap anak yang berhadapan dengan hukum agar anak dapat kembali ke dalam lingkungan sosial secara wajar, adalah marwah dari keadilan restoratif melalui diversi.

Proses ini terwujud ketika semua pihak yang terlibat dalam suatu perkara pidana tertentu bersama-sama mengatasi masalah serta menciptakan suatu kewajiban untuk membuat segala sesuatunya menjadi lebih baik dengan melibatkan korban, anak, dan masyarakat untuk mencari solusi dalam rangka memperbaiki, dan merekonsiliasi yang dalam prosesnya menentramkan hati dan tidak berdasarkan dendam. ${ }^{6}$

Kebijakan dalam menangani diversi sebenarnya wajib diupayakan dalam setiap sub sistem peradilan pidana baik pada tingkat penyidikan, penuntutan, dan pemeriksaan perkara anak di pengadilan negeri wajib diupayakan diversi. ${ }^{7}$ Kewajiban ini ditentukan sebagai berikut: ${ }^{8}$

1. Penyidikan dan penuntutan pidana anak yang dilaksanakan sesuai dengan ketentuan peraturan yang perundang-undangan, kecuali ditentukan lain dalam undang-undang ini (UU SPPA).

2. Persidangan anak yang dilakukan oleh pengadilan di lingkungan peradilan umum.

3. Pembinaan, pembimbingan, pengawasan, dan/atau pendampingan selama proses pelaksanaan pidana atau tindakan dan setelah menjalani pidana.

4. Dalam sistem peradilan pidana anak sebagaimana dimaksud pada ayat (2) hurus a dan b wajib diupayakan diversi.

Proses diversi dijalankan melalui musyawarah dengan melibatkan anak dan orang tua/walinya, korban dan atau orangtua/walinya, pembimbing kemasyarakatan, dan pekerja sosial profesional. Dalam hal jika diperlukan dapat melibatkan Tenaga Kesejahteraan Sosial, dan atau masyarakat. Dalam proses diversi harus memperhatikan hal-hal sebagai berikut: ${ }^{9}$

\footnotetext{
${ }^{6}$ Republik Indonesia, Undang-undang No. 11 tahun 2012 tentang Sistem Peradilan Pidana Anak pasal 1 angka 6

${ }^{7}$ Ibid, pasal 7

${ }^{8}$ Ibid, pasal 5 Ayat 2

${ }^{9}$ Ibid, Pasal 8
} 
1. Kepentingan korban

2. Kesejahteraan dan tanggung jawab anak

3. Penghindaran stigma negatif

4. Penghindaran pembalasan

5. Keharmonisan masyarakat

6. Kepatutan, kesusilaan, dan ketertiban umum

Baik Penyidik, Penuntut umum, Hakim dalam melakukan diversi harus mempertimbangkan kategori tindak pidana, umur anak, hasil penelitian dari Bapas, serta dukungan lingkungan keluarga dan masyarakat.

Selain undang-undang mengenai sistem peradilan pidana, Polri sendiri mempunyai keluwesan untuk melihat adanya potensi penanganan perkara tanpa harus melalui persidangan. Hal ini dikuatkan dengan hak diskresi yang dimiliki anggota Polri bahwa dalam rangka menyelenggarakan tugas di bidang pidana, Kepolisian Negara Republik Indonesia berwenang untuk: mengadakan tindakan lain menurut hukum yang bertanggung jawab. ${ }^{10}$ Tentunya dengan pertimbangan yang matang dan selaras dengan kewajiban hukum yang mengharuskan tindakan tersebut dilakukan, serta patut da masuk akal.

Polri juga dibekali arahan yakni dengan membangun pemahaman dalam suatu perbuatan anak dalam tindak pidana sebenarnya adalah akibat dari kegagalan atau kesalahan orang tua dalam mendidik maupun mengawal anak sampai pada usia dewasa. $^{11}$

Keseriusan dalam memberikan perlindungan anak dalam sistem peradilan juga di di wujudkan melalui keputusan bersama, yang kaitannya memperhatikan beberapa ketentuan melalui pasal 6 UU No.39 tahun 1999 tentang Ham dan dipertegas dalam pasal 16 UU No.23 tahun 2003 tentang perlindungan anak, yang mana beberapa poin intinya adalah: ${ }^{12}$

1. Tidak boleh dijatuhkan hukuman yang tidak manusiawi terhadap anak.

2. Hukuman mati/seumur hidup tidak boleh diberlakukan kepada anak.

3. Penangkapan, penahanan, pemidanaan harus berdasar hukum dan menempuh upaya terakhir.

Maksud dibentuknya Keputusan Bersama adalah mewujudkan keterpaduan dan Koordinasi dalam semua pihak yang terkait dalam menangani perkara $\mathrm{ABH}$.

${ }^{10}$ Republik Indonesia, Undang-Undang No. 2 Tahun 2002 tentang Polisi Republik Indonesia pasal 16 ayat 1

11 Telegram Kabareskrim Polri No. 1124/XI/2006 tentang Pedoman Pelaksanaan Diversi bagi Kepolisian, Telegram ini bersifat arahan untuk menjadi pedoman dalam pelaksanaan diversi. Dalam telegram ini disebutkan bahwa prinsip diversi yang terdapat dalam konvensi anak merupakan suatu bentuk pengalihan bentuk pidana dari proses peradilan formal menuju alternatif penyelesaian dalam bentuk lain yang dinilai terbaik demi kepentingan anak.

${ }^{12}$ Keputusan Bersama: Ketua Mahkamah Agung Republik Indonesia, Jaksa Agung Republik Indonesia, Kepala Kepolisian Negara Republik Indonesia, Menteri Hukum dan Ham Republik Indonesia, Menteri Sosial Republik Indonesia, dan Menteri Negara Pemberdayaan Perempuan dan Perlindungan Anak Republik Indonesia, Maksud dibentuknya Keputusan Bersama adalah mewujudkan keterpaduan dan Koordinasi dalam semua pihak yang terkait dalam menangani perkara ABH. 


\section{B. Hambatan Dalam Penerapan Sistem Diversi Dalam Rangka Memenuhi Keadilan Restoratif}

a. Faktor Masyarakat

Tidak dipungkiri bahwa pemahaman terhadap isi dari UU SPPA atau pemahaman mengenai diversi dan keadilan restoratif tidak cukup dalam. Hal ini jelas sangat berpengaruh melihat dalam penegakkan hukum harus dibarengi dengan pemahaman terhadap suatu aturan. Selain itu adanya kecenderungan yang kuat dalam masyarakat bahwa hukum sebagai penegak hukum atau petugas hukum, yang mana hal ini membuat masyarakat terbiasa melihat untuk suatu tindak pidana perlu adanya penghukuman. ${ }^{13}$

\section{b. Faktor Penegak Hukum}

Petugas penegak hukum mengambil peran penting dalam keberhasilan dan keberlangsungan diversi, kualitas petugas harus berbanding lurus dengan aturan yang sudah ada, di sini lah letak permasalahan yang kerapkali timbul bahwa beberapa oknum penegak hukum tidak melaksanakan ketentuan hukum sebagaimana mestinya. ${ }^{14}$ Mentalitas petugas harus terbentuk sebaik mungkin dalam rangka menjalankan undang-undang.

c. Hambatan Eksternal di Pengadilan Negeri Juga Sarana dan Prasarana

Dalam diversi sarana dapat mengacu kepada fasilitator, baik jaksa, hakim, juga penyidik seharusnya telah memiliki bekal yang cukup sebagai pelaksana diversi itu sendiri. Lalu kerjasama instansi lain terkait penerapan diversi yang belum bisa bersinergi dengan pengadilan maupun instansi yang terkait, hal ini yang dimasud prasarana selain ruangan khusus untuk mediasi, perlu adanya hubungan antara satu lembaga dengan lembaga yang lain.

d. Syarat Hukuman Harus di Bawah 7 tahun

Adanya anak-anak yang memang hukumannya dituntut di atas 7 tahun, hal ini tentu sangat sulit untuk dilakukan diversi karena diversi hanya dapat dilakukan oleh tindak pidana yang kurang dari 7 tahun atau terhitung 7 tahun, walau kembali lagi bila bicara anak maka output yang dihasilkan adalah hasil kegagalan yang berasal dari orangtua. ${ }^{15}$

\footnotetext{
${ }^{13}$ Soerjono Soekanto, "Faktor-faktor yang Mempengaruhi Penegakkan Hukum", Jakarta:RajaGrafindo Persada, Hal 55

${ }^{14}$ Sanyoto, "Penegakkan Hukum di Indonesia", Jurnal Dinamika Hukum, Vol 8 Universitas Jenderal Soedirman.

${ }^{15}$ Op.Cit, UU SPPA Pasal 7 ayat 1 dan 2
} 


\section{Hak Berpartisipasi Anak Dalam Diversi}

Dalam definisi tentang kategori anak, ialah mereka yang telah berumur 12 tahun tetapi belum berumur 18 tahun atau telah berumur 12 tahun meskipun sudah pernah kawin tetapi belum berumur 18 tahun. ${ }^{16}$

Lalu mengenai lamanya hukuman yang dapat diupayakan diversi dalam UU SPPA dikatakan bahwa diversi dapat di berlakukan pada perkara anak yang tuntutannya di bawah 7 tahun. Namun dalam Perma No.4 ada tersirat bahwa hukuman di atas 7 tahun dapat di upayakan, yang berbunyi "Hakim anak wajib mengupayakan diversi dalam hal anak didakwa melakukan tindak pidana yang diancam dengan pidana penjara di bawah 7 (tujuh) tahun dan didakwa pula dengan tindak pidana yang diancam dengan pidana penjara 7 (tujuh) tahun atau lebih dalam bentuk surat dakwaan subsidiaritas, alternatif, kumulatif maupun kombinasi (gabungan)”.

Kedua hal di atas setidaknya menjadi acuan pertama dalam mengukur kategori anak yang dapat mendapatkan diversi. Terlepas dari kategori yang ditentukan oleh undang-undang, setiap anak pada dasarnya memiliki hak berpartisipasi. Hak berpartisipasi adalah hak untuk menyatakan pendapat, yang dalam hal ini segala hal yang mempengaruhi anak.

Misalnya anak yang diputus pengadilan mendapat mati atau seumur hidup, yang mestinya dilarang dikarenakan pada pelanggar masih berusia muda. Termasuk anak-anak yang sudah menikah, maka status anak berubah menjadi orang dewasa, sehingga jika mereka melakukan pelanggaran hukum akan dilakukan seperti layaknya orang yang cakap hukum.

Kesalahan pengambilan keputusan baik oleh hakim, jaksa, dan penyidik memang tidak serta-merta disebabkan oleh adanya perbedaan definisi mengenai anak dalam setiap instrumen lokal. Rendahnya sosialisasi tentang perubahan peraturan dan rendahnya pemahaman personel di lapangan dalam menangani pelanggar usia muda, menyebabkan meningkatnya faktor variabel perbedaan usia secara signifikan.

Jika melihat kembali pada Konvensi Hak Anak ada beberapa poin menarik bahwa setiap anak pada dasarnya memiliki hak yang sama di peradilan terutama terkait upaya diversi, sebagai berikut: ${ }^{17}$

1. Non Discrimination, yaitu bertindak adil dan tidak membeda-bedakan anak

2. Kepentingan Terbaik Anak, yaitu mengupayakan semua keputusan, kegiatan, dan dukungan dari pihak yang berpengaruh semata-mata demi kepentingan anak

${ }^{16}$ Peraturan Mahkamah Agung No.4 Tahun 2014 pasal 2.

17 Op.Cit, The convention on the Rights of the Child, Negara berkewajiban untuk mengambil langkah-langkah legislatif, administratif, hukum, dan tindakan-tindakan lain untuk merealisasikan secara penuh hak asasi anak yang mana Berdasarkan Konvensi Hak Anak (KHA), pelaksanaan proses peradilan anak yang berhadapan dengan hukum ada empat prinsip yang harus diperhatikan. 
3. Mengutamakan hak anak untuk hidup, kelangsungan hidup dan tumbuh kembang, yaitu kegiatan disusun untuk perkembangan anak berdasarkan kemampuan dan tugas-tugas perkembangannya

4. Menghormati pandangan anak, yaitu memperhatikan dan memasukkan pandangan anak dalam setiap proses pembahasan dan pengambilan keputusan setiap kegiatan

Kembali lagi, perlu diingat bahwa anak sangat erat kaitannya dengan HAM, yang mana setiap orang berhak atas perlindungan hak asasi manusia dan kebebasan manusia tanpa diskriminasi. ${ }^{18}$ Semakin jelas bahwa anak berhak dilindungi sebagai suatu entitas yang bernilai harganya, dan ketika bermasalah dengan hukum salah satu jalannya adalah menggunakan diversi karena diversi merupakan cara melindungi HAM.

Sedikit meninjau ke belakang bahkan jauh sebelum UU SPPA lahir concern mengenai hak anak telah dijelaskan secara tidak langsung bahwa konsep diversi merupakan suatu konsep yang bertujuan untuk pemenuhan HAM dan Hak Anak. Ada beberapa poin yang dijabarkan yaitu: ${ }^{19}$

1. Pasal 2: Anak berhak atas perlindungan terhadap lingkungan hidup yang dapat membahayakan atau menghambat pertumbuhan dan perkembangannya dengan wajar

2. Pasal 6 ayat (1): Anak yang mengalami masalah kelakuan diberi pelayanan dan asuhan yang bertujuanmenolongnya guna mengatasi hambatan yang terjadi dalam masa pertumbuhan danperkembangannya

3. Pasal 6 ayat (2): Pelayanan dan asuhan, sebagaimana dimaksudkan dalam ayat (1), juga diberikan kepada anak yang telah dinyatakan bersalah melakukan pelanggaran hukum berdasarkan keputusan hakim

Segala bentuk aturan dan kebijakan terkait perlindungan anak telah dicoba untuk di implementasikan sedemikian rupa, dan yang terpenting jangan sampai ada faktor yang membeda-bedakan dalam penanganan anak mengingat "semua orang sama di depan hukum dan berhak atas perlindungan hukum yang sama tanpa diskriminasi. Semua berhak atas perlindungan yang sama terhadap setiap bentuk diskriminasi yang bertentangan dengan Deklarasi ini, dan terhadap segala hasutan yang mengarah pada diskriminasi", ${ }^{20}$

Dalam pemenuhan HAM dan Hak Anak maka konsep diversi sangat cocok dan diperlukan. Sehingga pada intinya, implementasi konsep diversi terhadap pemenuhan HAM dan Hak Anak telah diakomodir sedemikian rupa baik oleh negara maupun internasional. Hal ini karena banyak negara yang berpandangan bahwa HAM dan hak anak merupakan suatu hak yang fundamental yang harus diperhatikan dan dilindungi, mengingat anak adalah generasi bangsa yang akan melanjutkan perdaban.

\section{KESIMPULAN}

Penghukuman bagi pelaku tindak pidana anak tidak kemudian mencapai keadilan bagi

\footnotetext{
${ }^{18}$ Republik Indonesia, Undang-undang No.39 tahun 1999 tentang Ham pasal 3 angka 3

${ }^{19}$ Republik Indonesia, Undang-undang No.4 tahun 1979 tentang Kesejahteraan Anak.

${ }^{20}$ Deklarasi Universal Hak Asasi Manusia (DUHAM) yang diterima dan diumumkan oleh Majelis Umum Perserikatan Bangsa-bangsa (PBB) pada tanggal 10 Desember 1948, Pasal 7.
} 
korban, mengingat dari sisi lain masih meninggalkan permasalahan tersendiri yang tidak terselesaikan meskipun pelaku telah di hukum. Melihat prinsip-prinsip tentang perlindungan anak terutama prinsip mengutamakan kepentingan terbaik bagi anak maka diperlukan proses penyelesaian perkara anak di luar mekanisme pidana atau biasa disebut diversi. Melalui UU SPPA (Sistem Peradilan Pidana Anak) diharapkan mampu mengakomodir amanat dari Undang-undang dasar, Undang-undang No.3 tahun 1997 tentang Pengadilan Anak serta aturan lain secara maksimal.

Diversi saat ini merupakan alternatif penyelesaian permasalahan bagi anak yang berhadapan dengan hukum secara progresif. Dalam penerapannya walaupun masih ada anak-anak yang belum mendapatkan upaya diversi oleh dikarenakan kurangnya pemahaman maupun aturan yang jelas, namun sebagai suatu hak yang mendasar diversi diharapkan mampu untuk diberikan kepada setiap anak yang berkonflik dengan hukum, tanpa membeda-bedakan apapun, sehingga marwah keadilan restoratif yang merupakan suatu bentuk pembaharuan hukum yang bukan hanya sekedar mengubah undang-undang, namun juga memodifikasi sistem peradilan yang ada, dapat sampai kepada setiap anak.

\section{SARAN}

Perlu melibatkan lebih banyak unsur masyarakat maupun Lembaga Swadaya Masyarakat (LSM) terutama dalam program pencegahan $\mathrm{ABH}$ dan program after care bagi $\mathrm{ABH}$.

Berpedoman pada prinsip yang terbaik untuk anak, maka beberapa lembaga yang menjadi tempat penitipan ataupun tempat menjalani hukuman $\mathrm{ABH}$ seperti LPKA dan panti sosial lainnya menyediakan berbagai sarana dan prasarana dalam mendukung tumbuh kembang anak yang lebih baik.

Mendorong berbagai pihak untuk semakin mengintensifkan penyelesaian kasus hukum anak (sebagai pelaku) melalui prinsip restorative justice dengan cara diversi, sekaligus memastikan bahwa proses diversi tidak sekedar sebagai sarana traksaksi ganti rugi, tetapi tetap mampu memberi efek jera kepada anak sebagai pelaku hukum.

Perlu melakukan sosialisasi kepada masyarakat terkait dengan proses hukum anak yang berbeda dengan proses hukum orang dewasa untuk mencegah pemahaman yang keliru dari masyarakat tentang proses hukum yang berjalan.

Memperbaiki atau melakukan judicial review dalam rangka mencari titik kelemahan yang membuat diversi kurang berjalan.

Melakukan pelatihan dan pendalaman terkait dengan keadilan restoratif juga diversi kepada para penegak hukum, sehingga dapat lebih menjiwai aturan itu sendiri.

\section{DAFTAR PUSTAKA}

Deklarasi Universal Hak Asasi Manusia (The Universal Declaration on Human Rights) DUHAM, 1948.

Konvensi hak anak (Convention on the Rights of the Child article), 1989. 
Supeno Hadi, 2010, “Kriminalisasi anak, Tawaran Gagasan Radikal Peradilan Anak Tanpa Pemidanaan”, Jakarta: PT. Gramedia.

Soekanto Soerjono, 2013, "Faktor-faktor yang Mempengaruhi Penegakkan Hukum", Jakarta:Raja Grafindo Persada.

Sanyoto, "Penegakkan Hukum di Indonesia", dalam Jurnal Dinamika Hukum, Vol 8 Universitas Jenderal Soedirman, diakses pada tanggal 12 Juni 2021 pukul 16.21 WIB.

Al Adawiah, R. (2019). Child Abuse Dan Keamanan Lingkungan Anak Dalam Menyongsong Bonus Demografi 2025-2030. Krtha Bhayangkara, 13(1). https://doi.org/10.31599/krtha.v13i1.13

Laksana, P. B. ., \& Sugeng. (2020). Pendekatan Keadilan Restoratif Terhadap Anak Sebagai Pelaku Pelanggaran Lalu Lintas. Jurnal Hukum Sasana, 5(1). https://doi.org/10.31599/sasana.v5i1.91

\section{Peraturan Perundang-Undangan}

Undang-undang Republik Indonesia No. 11 tahun 2012 tentang Sistem Peradilan Pidana Anak.

Undang-undang Republik Indonesia, No. 2 Tahun 2002 tentang Polisi Republik Indonesia.

Undang-undang Republik Indonesia, No. 39 tahun 1999 tentang Hak Asasi Manusia.

Undang-undang Republik Indonesia, No. 4 tahun 1979 tentang Kesejahteraan Anak.

Undang-undang Dasar Republik Indonesia 1945.

Keputusan Bersama: Ketua Mahkamah Agung Republik Indonesia, Jaksa Agung Republik Indonesia, Kepala Kepolisian Negara Republik Indonesia, Menteri Hukum dan Ham Republik Indonesia, Menteri Sosial Republik Indonesia, dan Menteri Negara Pemberdayaan Perempuan dan Perlindungan Anak Republik Indonesia, tentang Penanganan Anak yang Berhadapan Dengan Hukum

Peraturan Mahkamah Agung No. 4 Tahun 2014 tentang Pedoman Pelaksanaan Diversi Dalam Sistem Peradilan Anak

Telegram Kabareskrim Polri No. 1124/XI/2006 tentang Pedoman Pelaksanaan Diversi Bagi Kepolisian 
Available online at: http://ejurnal.ubharajaya.ac.id/index.php/sasana 